\title{
Influence of variety and weather conditions on fatty acid composition of winter and spring Camelina sativa varieties in Poland
}

\author{
Danuta Kurasiak-Popowska ${ }^{1}$ - Małgorzata Graczyk ${ }^{2}$ (D) $\cdot$ Anna Przybylska-Balcerek ${ }^{3} \cdot$ Kinga Stuper-Szablewska $^{3}(1)$
}

Received: 3 August 2020 / Revised: 22 October 2020 / Accepted: 24 October 2020 / Published online: 12 November 2020

(c) The Author(s) 2020

\begin{abstract}
The aim of this study was to determine the influence of weather conditions over the course of 4 years (2016-2019) on the fatty acid profile of Camelina sativa. It was assumed that varieties and functional forms of plants (spring and winter genotypes) were characterized by a different fatty acid composition and that weather conditions affected the profile of fatty acids in camelina seeds. Statistical analyses were performed based on the results of chemical tests. Differences were found in the mean concentrations of C18:3n3, C18:3n6, C20:2 and C22:1 acids in all genotypes based on the Kruskal test. Two winter genotypes (Maczuga and 15/2/3) and the spring genotype UP2017/02 had the significantly highest content of C18:3n6. Genotypes CSS-CAM31, CSS-CAM30, BRSCHW 28347, CSS-CAM36 and Kirgzkij showed the highest content of C18:3n3. The lowest C18:3n3 content was found in winter genotypes: K9/1, 15/2/3, Przybrodzka (winter form) and C5. It was found that weather conditions deviating from the long-term average, both in terms of temperature and precipitation, did not affect the quantitative profile of fatty acids. Over the 4 years, no differences were observed in the fatty acid profile between the spring and winter forms. Observations made in this study allow to state that spring and winter forms of Camelina sativa retain a constant fatty acid composition regardless of changing weather conditions.
\end{abstract}

Keywords UPLC $\cdot$ Fatty acids $\cdot$ Camelina sativa $\cdot$ Weather conditions

Electronic supplementary material The online version of this article (https://doi.org/10.1007/s00217-020-03639-0) contains supplementary material, which is available to authorized users.

Danuta Kurasiak-Popowska

danuta.kurasiak-popowska@up.poznan.pl

Małgorzata Graczyk

malgorzata.graczyk@up.poznan.pl

Anna Przybylska-Balcerek

ania_przybylska18@wp.pl

Kinga Stuper-Szablewska

kinga.stuper@up.poznan.pl

1 Department of Genetics and Plant Breeding, Faculty of Agronomy, Horticulture and Bioengineering, Poznan University of Life Sciences, Dojazd 11, 60-632 Poznan, Poland

2 Department of Mathematical and Statistical Methods, Faculty of Agronomy, Horticulture and Bioengineering, Poznan University of Life Sciences, Wojska Polskiego 28, 60-637 Poznan, Poland

3 Department of Chemistry, Faculty of Forestry and Wood Technology, Poznan University of Life Sciences, Wojska Polskiego 75, 60-625 Poznan, Poland

\section{Introduction}

For over a dozen years, we have been struggling with the problem of limited water resources and necessity of improving the water balance. In the last few decades, droughts occur increasingly often, they are more intense and cover larger areas. The negative effects of drought are visible especially in agriculture and adverse hydrological changes.

Poland is located in the temperate zone in the region of Central Europe [1]. The average annual rainfall in Poland ranges $500-550 \mathrm{~mm}$ in the central part to over $700 \mathrm{~mm}$ in the north and $1000 \mathrm{~mm}$ in the south of the country [2]. Another problem is the very high precipitation variability in years in individual months, while similar annual sum [3]. Both water excess and deficiency are an important stress factor for plants, classified to the group of abiotic stressors. The negative impact of this phenomenon intensifies variable water demand of plants during the growing season. Typically, the highest water demand occurs at the end of the vegetative development stage and the beginning of generative organ formation and is defined as the critical sensitivity phase, in which moisture deficiency causes the 
greatest yield reductions [4]. Therefore, it is very important to select the appropriate crop species and varieties for sowing.

Camelina sativa originates from Eastern Europe and Western Asia and is one of the most resistant plants to biotic and abiotic stresses from the family Brassicaceae [5]. Camelina is highly adaptable to various climatic and soil conditions [6]. It is most often cultivated in poor and very poor soils, unsuitable for the cultivation of more demanding species. It is well known that rainfall deficiency is particularly significant in lighter soils, where precipitaion demands are about $20 \%$ greater than in medium soils. Camelina is probably the least sensitive to soil water deficiency of all plants of the family Brassicaceae. The interest in camelina mainly results from the wide possibilities of this plant utilization, and above all due to the high oil content in the seeds, amounting to about $40 \%[7,8]$. Camelina seeds are rich in oleic acid (18:1), linoleic acid (18:2), linolenic acid (18:3) and eicosenoic acid (20:1) [9]. Traditionally, camelina oil has been mainly used for food purposes. Currently, the most attention is paid to the use of camelina oil in the production of diesel oil and for use as aviation fuel $[6,10]$. Camelina oil can also be utilized as a source of biologically active compounds in the food and cosmetic industries [11]. Camelina fatty acid composition allowed to successfully use it in the petrochemical-based polymer industry and for the production of pressure-sensitive adhesives, coatings and resins [12].

Camelina pomace, a by-product of oil extraction, can be used as a protein-rich component of animal feed mixtures [13-15]. Stems, on the other hand, are a valuable raw material for the production of pulp and improved products, such as paper, OSB boards, etc. [16].

The possibilities of camelina application are extensive, and cultivation of this plant is undemanding. Additional advantages are its predispositions to cultivation in ecological conditions. Camelina is one of the old-lineage plants that easily adapt their vegetation to climatic changes, which has been confirmed by previous studies on its resistance to temperature and hydrological fluctuations. For farmers and consumers, in addition to resistance or yield size, it is also important that the plant retains a stable fatty acid profile, which is beneficial for the diet, especially for people suffering from civilization diseases.

The aim of this study was to determine the effect of weather conditions over the course of 4 years on the fatty acid profile of Camelina sativa. Considering literature reports on oilseed rape and other oilseed crops, indicating a significant variability in seed fatty acid composition, it was decided to verify the following research hypotheses:

- Weather conditions affect the profile of fatty acids in Camelina sativa seeds.
- Varieties and functional forms of plants (spring and winter) are characterized by different fatty acid composition.

\section{Materials and methods}

\section{Chemicals}

Methanol and acetonitrile were HPLC grade (SigmaAldrich, St. Louis, MO, USA); hydrochloric acid and natrum hydroxide were purchased from POCH S.A (Gliwice, Poland); deionized water was prepared using a Millipore Milli-Q system (Millipore, MA, USA). Methyl erucate standards were purchased from Sigma-Aldrich (St. Louis, MO, USA.).

\section{Plant material}

Sixty-three spring genotypes of camelina were evaluated: 44 biotypes were acquired from the US National Plant Germplasm System (NPGS), USA and 19 genotypes from the collection of the Department of Plant Genetics and Breeding, Poznań University of Life Sciences, Poland (SM Table 1). The following 11 winter camelina genotypes were analyzed: 'Maczuga', 'Przybrodzka' and 'Luna' as well as 8 other genetically stable mutation lines. In 2008, the genotype 'Przybrodzka' was registered in the National Plant Breeders' Rights in Poland. The genotypes 'Luna' and 'Maczuga', which were bred at the Department of Plant Genetics and Breeding, Poznań University of Life Sciences (Poland), were registered in the National Plant Breeders' Rights in Poland in 2012. These genetically stable lines were bred at the Department of Plant Genetics and Breeding when seeds of the genotype 'Przybrodzka' were irradiated with four doses of gamma rays (0 Gy, $200 \mathrm{~Gy}, 400 \mathrm{~Gy}, 600 \mathrm{~Gy}$ ) from the ${ }^{60}$ Co source in 1993.

\section{Field test}

Field experiments were conducted during 2016-2019 growing seasons at the Agricultural Research Station in Dłon, Poznan University of Life Sciences, Poland (51 $41^{\prime} 37^{\prime \prime}$ N $17^{\circ} 04^{\prime} 06^{\prime \prime} \mathrm{E}$ ), located $110 \mathrm{~km}$ south of Poznań in the Wielkopolska Region of western Poland. The experiment was established as a randomized block design of three replicates on haplic luvisol soil. Spring and winter genotypes were grown separately. The experiments were conducted under conventional tillage and soybean was the previous crop. Spring genotypes were sown between March 25 and April 10, whereas winter ones were sown between September 25 and October 5. The field management followed standard agricultural practice. Diseases and pests were not controlled. The plants were left standing in the field until 
completely maturation. The grain yield was adjusted for $9 \%$ moisture content. Spring genotypes were harvested between July 25 and August 10, whereas winter ones were harvested from July 10 to 30 .

The average monthly temperatures and precipitation, measured according to the WMO guidelines for the years 2016-2019, were obtained from a Vantage Vue 6357 UE 9 meteorological station (Davis Instruments) located approx. $400 \mathrm{~m}$ from the experimental field.

\section{Fatty acid extraction}

Fatty acids were extracted using the method described by Stuper-Szablewska (2014). Samples containing $100 \mathrm{mg}$ of ground grains were placed in 17-ml culture tubes, suspended in $2 \mathrm{ml}$ of methanol, treated with $0.5 \mathrm{ml}$ of $2 \mathrm{M}$ aqueous sodium hydroxide, and tightly sealed. The culture tubes were then placed in 250-ml plastic bottles, sealed tightly and placed inside a microwave oven (Model AVM 401/1WH; Whirlpool, Sweden) operating at 2,450 MHz and a maximum output of $900 \mathrm{~W}$. The samples were irradiated $(370 \mathrm{~W})$ for $20 \mathrm{~s}$. After about $5 \mathrm{~min}$, they were irradiated for another $20 \mathrm{~s}$. After $15 \mathrm{~min}$, the contents of the culture tubes were neutralized with $1 \mathrm{M}$ aqueous hydrochloric acid; $2 \mathrm{ml}$ of $\mathrm{MeOH}$ was added and extraction was carried out with pentane (3-4 ml) in the culture tubes. The combined pentane extracts were evaporated to dryness under a nitrogen stream. Next, the extracts were methylated with a mixture of anhydrous methanol and sulphuric acid $(1: 5, \mathrm{v} / \mathrm{v})$. The extract containing lipids was mixed with $0.5 \mathrm{ml}$ of methanol. Subsequently, a $0.15-\mathrm{ml}$ mixture of methanol and sulphuric acid $(1: 5, \mathrm{v} / \mathrm{v})$ was added. The samples were heated at $70{ }^{\circ} \mathrm{C}$ for $15 \mathrm{~min}$. After cooling the solution, $0.5 \mathrm{ml}$ of $n$-hexane was added. Next, water was added at a sufficient volume to form two layers. The upper hexane layer was aspirated and analyzed.

\section{Fatty acid profile (FAME) analysis by UPLC}

Fatty acids were analyzed using an Acquity UPLC H-class system with a Waters Acquity PDA detector (Waters, USA). An Acquity UPLC@ BEH $\mathrm{C}_{18}$ column $(150 \mathrm{~mm} \times 2.1 \mathrm{~mm}$, particle size $1.7 \mu \mathrm{m}$ ) (Waters, Ireland) was used for chromatographic separation. The following mobile-phase composition was used for gradient elution: A: acetonitrile; B: 2-propanol, flow: $0.17 \mathrm{ml} / \mathrm{min}$. Sterol concentrations were measured with an external standard at wavelengths of $\lambda=195-300$. Compounds were identified by comparing the retention times of the examined peak with that of the standard and by adding a specific amount of the standard to the tested sample. The analyses were repeated.

\section{Statistical analysis}

For basic descriptive statistics, all genotypes (74) were evaluated individually with regard to the content of individual acids (19) (SM). Mean values and standard deviations were determined. Moreover, descriptive statistics were determined for the content of 19 acids separately for spring and winter genotypes. The mean value, standard deviation, median and standard error of the mean as well as the respective minimum and maximum are presented in Table 1.

The relationships between genotypes are presented in the dendrogram. In this case, the Ward's minimum variance method was a criterion applied in hierarchical cluster analysis. The Euclidean distance between each pair of observations was used to classify the observations into groups.

The interaction plot displays the fitted values of the dependent variable on the $y$-axis (the content of selected acid in the tested variety), while the $x$-axis shows the values of the first independent variable (acids); different lines represent the values of the second independent variable. Parallel lines in the interaction plot, indicate that there is no interaction effect, while different slopes suggest that this effect can be present.

The data were analyzed according to the following statistical model: $y_{i j k}=m+a_{i}+b_{j}+e_{i j k}$ $y_{i k}=m+a_{i}+e_{i k} \quad y_{i k}^{s}=m^{s}+a_{i}^{s}+e_{i k}^{s}$, where $y_{i k}^{s} \quad$ is the content of sth acid in $i$ th genotype in $k$ th year, $m \mathrm{~m}^{s}$ is the overall mean of of sth acid content, $s \in\{\mathrm{C} 18: 1, \mathrm{C} 18: 2 \mathrm{n} 6, \mathrm{C} 18: 3 \mathrm{n} 6, \mathrm{C} 18: 3 \mathrm{n} 3, \mathrm{C} 20: 1$, C20 : 2, C22 : 1\} $a_{i} a_{i}^{s}$ is the effect of the $i$ th level of factor $A$ for sth acid, $e_{i k}^{s} e_{i j k} e_{i k}$ is the experimental error for $i$ th unit and sth acid and $k$ is the number of replications, $s \in\{\mathrm{C} 18: 1, \mathrm{C} 18: 2 \mathrm{n} 6, \mathrm{C} 18: 3 \mathrm{n} 6, \mathrm{C} 18: 3 \mathrm{n} 3, \mathrm{C} 20: 1$, $\mathrm{C} 20: 2, \mathrm{C} 22: 1\}$. The evaluation of statistically significant differences attributable to acid contents was carried out on the basis of Kruskal-Wallis test due to the lack of normal distribution. The Dunn test was used as the post hoc analysis to determine homogeneity groups. The data were analyzed in the package $\mathrm{R}$.

\section{Results and discussion}

The basis of this research was the assumption that in contrast to other oil plants, Camelina sativa, as an old lineage of oil plants, is more stable in terms of the content of bioactive fatty acids. Four-year studies of the fatty acid profile of 63 spring genotypes and 11 winter genotypes cultivated in the same agricultural conditions were to provide a phenomenological basis for the verification of research hypotheses presented in the Introduction.

A high variability of weather conditions was observed during 4 years of research (Fig. 1). Taking into account 
Table 1 Descriptive statistics of the fatty acids in spring (S) and winter (W) C. sativa samples

\begin{tabular}{|c|c|c|c|c|c|}
\hline Fatty acid (\%) & Mean \pm SD & SE & Median & Min & Max \\
\hline \multicolumn{6}{|l|}{ C14:0 } \\
\hline S & $0.006 \pm 0.2462$ & 0.0016 & 0.00 & 0.00 & 0.20 \\
\hline W & $0.108 \pm 0.0953$ & 0.0144 & 0.10 & 0.00 & 0.40 \\
\hline \multicolumn{6}{|l|}{$\mathrm{C} 15: 0$} \\
\hline $\mathrm{S}$ & $0.003 \pm 0.1647$ & 0.0010 & 0.00 & 0.00 & 0.10 \\
\hline W & $0.109 \pm 0.0742$ & 0.0112 & 0.10 & 0.00 & 0.30 \\
\hline \multicolumn{6}{|l|}{ C16:0 } \\
\hline S & $5.182 \pm 1.8222$ & 0.1148 & 5.15 & 2.10 & 9.00 \\
\hline W & $8.404 \pm 1.9532$ & 0.2945 & 8.75 & 4.60 & 11.30 \\
\hline \multicolumn{6}{|l|}{$\mathrm{C} 17: 0$} \\
\hline$S$ & $0.007 \pm 0.0258$ & 0.0017 & 0.00 & 0.00 & 0.10 \\
\hline W & $0.150 \pm 0.0849$ & 0.0128 & 0.15 & 0.00 & 0.30 \\
\hline \multicolumn{6}{|l|}{ C18:0 } \\
\hline$S$ & $1.877 \pm 0.5035$ & 0.0317 & 1.80 & 1.00 & 3.00 \\
\hline W & $2.396 \pm 0.3537$ & 0.0533 & 2.40 & 1.80 & 3.30 \\
\hline \multicolumn{6}{|l|}{ C20:0 } \\
\hline$S$ & $0.717 \pm 0.3543$ & 0.0223 & 0.70 & 0.10 & 1.50 \\
\hline W & $1.084 \pm 0.4194$ & 0.0632 & 1.10 & 0.30 & 1.80 \\
\hline \multicolumn{6}{|l|}{$\mathrm{C} 21: 0$} \\
\hline$S$ & $0.099 \pm 0.1609$ & 0.0101 & 0.1 & 0.0 & 2.0 \\
\hline W & $0.002 \pm 0.0151$ & 0.0023 & 0.00 & 0.00 & 0.10 \\
\hline \multicolumn{6}{|l|}{$\mathrm{C} 24: 0$} \\
\hline S & $0.064 \pm 0.0778$ & 0.0049 & 0.00 & 0.00 & 0.30 \\
\hline W & $0.197 \pm 0.1513$ & 0.0228 & 0.20 & 0.00 & 0.60 \\
\hline \multicolumn{6}{|l|}{ C15:1 } \\
\hline S & $0.006 \pm 0.0253$ & 0.0016 & 0.00 & 0.00 & 0.20 \\
\hline W & $0.128 \pm 0.0863$ & 0.0130 & 0.10 & 0.00 & 0.30 \\
\hline \multicolumn{6}{|l|}{$\mathrm{C} 16: 1$} \\
\hline $\mathrm{S}$ & $0.001 \pm 0.0141$ & 0.0009 & 0.00 & 0.00 & 0.20 \\
\hline $\mathrm{W}$ & $0.426 \pm 0.2192$ & 0.0330 & 0.42 & 0.10 & 0.90 \\
\hline \multicolumn{6}{|l|}{$\mathrm{C} 17: 1$} \\
\hline$S$ & $0.010 \pm 0.0318$ & 0.0020 & 0.00 & 0.00 & 0.20 \\
\hline W & $0.170 \pm 0.0734$ & 0.0111 & 0.17 & 0.10 & 0.31 \\
\hline \multicolumn{6}{|l|}{ C18:1 } \\
\hline S & $14.31 \pm 2.672$ & 0.1683 & 14.60 & 9.50 & 20.00 \\
\hline W & $15.78 \pm 1.5702$ & 0.2367 & 15.80 & 10.60 & 18.60 \\
\hline \multicolumn{6}{|l|}{ C20:1 } \\
\hline S & $19.50 \pm 5.140$ & 0.3238 & 18.45 & 12.00 & 31.50 \\
\hline W & $18.744 \pm 3.6109$ & 0.5444 & 18.38 & 13.10 & 30.00 \\
\hline \multicolumn{6}{|l|}{$\mathrm{C} 22: 1$} \\
\hline S & $3.369 \pm 0.6052$ & 0.0381 & 3.30 & 2.00 & 4.50 \\
\hline W & $0.099 \pm 0.0985$ & 0.0148 & 0.10 & 0.00 & 0.40 \\
\hline \multicolumn{6}{|l|}{$\mathrm{C} 24: 1$} \\
\hline S & $0.553 \pm 0.2753$ & 0.0173 & 0.50 & 0.10 & 1.10 \\
\hline W & $0.548 \pm 0.3396$ & 0.0512 & 0.60 & 0.00 & 1.10 \\
\hline \multicolumn{6}{|l|}{ C18:2n6 } \\
\hline S & $13.266 \pm 2.310$ & 0.1455 & 13.00 & 9.60 & 18.00 \\
\hline W & $14.890 \pm 1.6077$ & 0.2424 & 14.72 & 12.10 & 18.50 \\
\hline C18:3n6 & & & & & \\
\hline
\end{tabular}

Table 1 (continued)

\begin{tabular}{lcllll}
\hline Fatty acid (\%) & Mean \pm SD & SE & Median & Min & Max \\
\hline S & $0.020 \pm 0.0484$ & 0.0031 & 0.00 & 0.00 & 0.30 \\
W & $0.195 \pm 0.1843$ & 0.0278 & 0.15 & 0.00 & 0.99 \\
C18:3n3 & & & & & \\
S & $39.930 \pm 4.295$ & 0.2705 & 40.245 & 26.00 & 51.10 \\
W & $35.786 \pm 3.7597$ & 0.5668 & 35.91 & 28.50 & 45.90 \\
C20:2 & & & & & \\
S & $0.996 \pm 0.3245$ & 0.0204 & 0.90 & 0.50 & 1.80 \\
W & $0.712 \pm 0.2935$ & 0.0443 & 0.70 & 0.30 & 1.70 \\
\hline
\end{tabular}

the average precipitation in the period from April to July over 53 years (1956-2009), $235 \mathrm{~mm}$ was recorded in Dlon. In 2016 , total precipitation for the same time period was $312 \mathrm{~mm}$, in $2017-266 \mathrm{~mm}$, in $2018-268 \mathrm{~mm}$ and only $132 \mathrm{~mm}$ in 2019. Comparing the temperature in individual years of the study, it can be noticed that significantly higher air temperatures in April $\left(14.4^{\circ} \mathrm{C}\right)$ and May $\left(18.4^{\circ} \mathrm{C}\right)$ were recorded in 2018 , while the average monthly air temperatures in the remaining years of the study were similar to the average long-term temperatures, i.e. $8.2{ }^{\circ} \mathrm{C}$ for April and $13.5^{\circ} \mathrm{C}$ for May. The average long-term temperature in June is $16.8^{\circ} \mathrm{C}$. In the years of the research, the average air temperature in June was $21^{\circ} \mathrm{C}(2016), 19^{\circ} \mathrm{C}(2017), 19.7^{\circ} \mathrm{C}$ (2018) and $23.7^{\circ} \mathrm{C}$ in 2019. Average air temperatures in July fluctuated from $19.5^{\circ} \mathrm{C}$ to $21^{\circ} \mathrm{C}$. In summary, 2018 was characterized by the highest temperatures in the spring, while 2019 was characterized by the highest temperatures during the growing season with a simultaneous very low rainfall. Thus, during the study years, very different weather conditions were observed, which could affect the content of the analyzed compounds.

The coefficients of variation, being the quotient of standard deviation of a trait and its arithmetic mean, were determined to compare acid contents for individual years of research and considered varieties. The calculated coefficient for each variety and each acid separately was not higher than 27\%. A low value of the coefficient of variation indicated low heterogeneity of the tested trait (acid contents) and proved the homogeneity of the population (tested varieties for each acid separately). Therefore, it can be assumed that there are no significant differences in the content of tested acids for individual varieties between years. Different weather conditions in the years of research did not affect the percentage of individual fatty acids in the spring and winter genotypes of camelina.

The above statement is consistent with the results of Schulte et al., who analyzed the effect of temperature on the fatty acid profile of 4 oilseed species (spring oilseed rape, camelina, soybean and sunflower) [17]. Temperature increase from 10 to $40{ }^{\circ} \mathrm{C}$ during grain filling resulted in a 
Fig. 1 Rainfall and average air and Aug 2019, Dłoń, Poland temperatures between Sept 2015

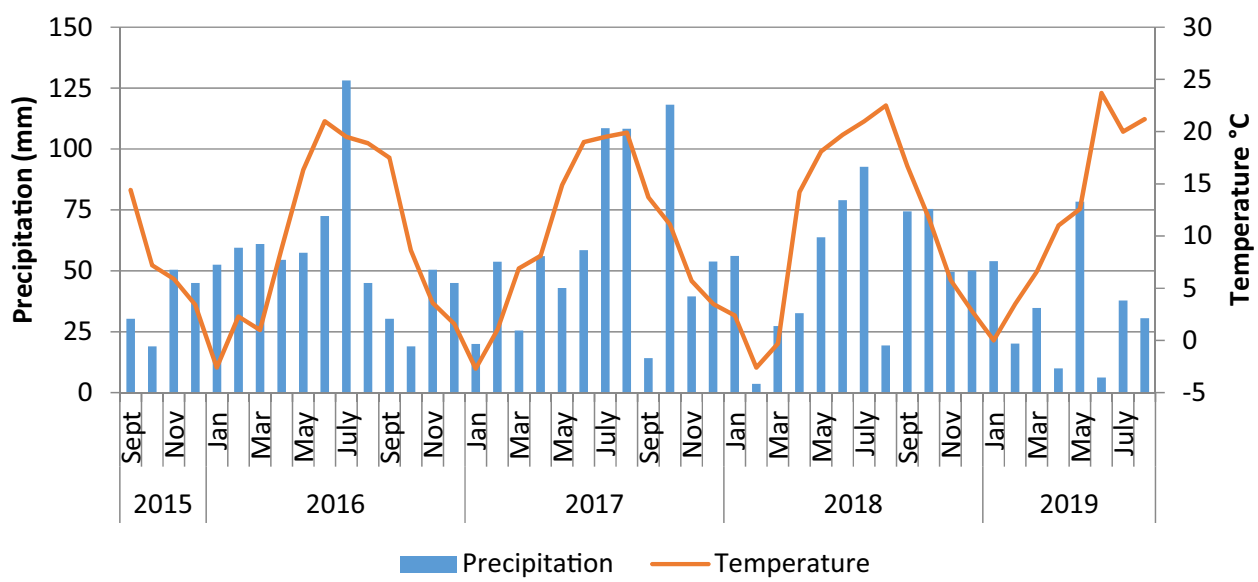

higher oleic acid production and a decrease in the production of linoleic acid and linolenic acid in soybeans, oilseed rape and sunflower. The authors unequivocally established that the lipid profile of camelina was insensitive to temperature changes [17]. Similarly, Jiang et al. found that the temperature during vegetation had no effect on fatty acid composition of 5 camelina genotypes. The authors also did not observe any correlation between rainfall and the quality of camelina seeds [18]. However, other authors reported temperature effect on the final fatty acid composition of camelina. Other authors showed the effect of temperature on the activity of desaturases [19] and fatty acid incorporation to triacylglycerol molecules [20]. Righini et al. et al. studied the effects of different sowing dates on the spring variety Midas and found that the autumn sowing dates of this variety in Italy increased the content of linolenic and eicosenoic acid [21]. The latter authors reported that the sowing date directly influenced the temperature during the grain filling stage, and was therefore related to the final quality of the oil.

On the other hand, many authors observed changes in camelina fatty acid profile caused by soil and agrotechnical factors. A 2-year field study with five environments (siteyears) of Camelina sativa showed that the fatty acid profile differed depending on the location and soil conditions [18]. The percentage increase in PUFA content and a simultaneous decrease in MUFA were observed along with the increase in nitrogen fertilization $[18,22]$.

The next stage of the research was to determine the variability of the fatty acid profile between varieties. Figure 2 shows the interaction plot; levels of one variable (fatty acids) are on the OX axis. A separate curve was made for the means of each level of the second variable, i.e. the variety. The curves corresponding to the content of individual acids in the considered varieties were almost parallel. This meant that there was no interaction between the varieties and individual acids. As a result, trends in acid content changes were analogous regardless of the research year.
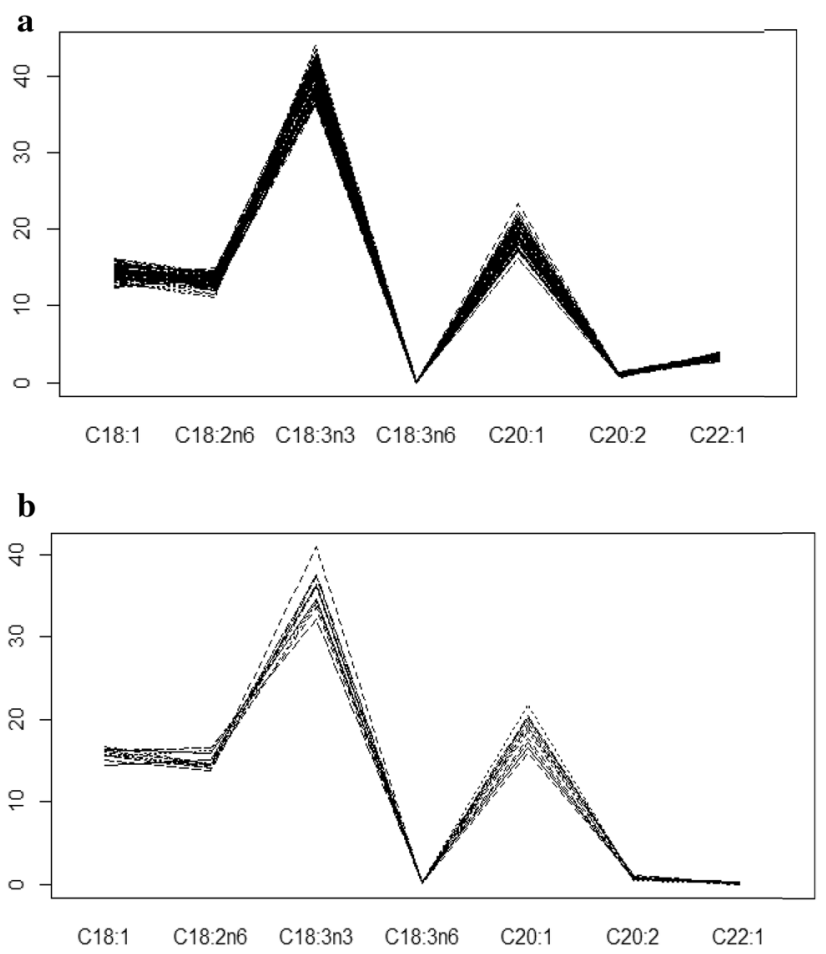

Fig. 2 Interaction plots between acids and varieties for spring (a) and winter (b) genotypes o Camelina sativa

C18:3n3 was the dominant fatty acid, belonging to the group of polyunsaturated acids, whose content in spring varieties ranged from 26 to $51.1 \%$, while in winter varieties from 28.5 to $45.9 \%$ (Table 1). The average content of this acid was $39.9 \%$ (for spring genotypes) and $35.7 \%$ (for winter genotypes) of all fatty acids present in camelina seeds (Table 1). Large differences in C18:3n3 content between the spring genotypes of Camelina sativa were also observed by other authors. Linoleic acid content was shown to vary from 25.1 to $32.4 \%$ [23], 31.62 to $34.32 \%$ [24] and from $34.7-37.1 \%$ [25] to $34.1-41.2 \%$ [26]. Such a large range of 
the results was caused by the genotype, agronomic treatment or environmental conditions [27].

Acids belonging to the MUFA family were second in terms of the content (SM, Tables 3,6). The average content of all MUFA acids was $38.72 \%$ for spring forms and $36.58 \%$ for winter forms. Among MUFA acids, the highest content was recorded for C20:1 (an average of 19.5\% for spring forms and 18.74 for winter ones) and C18:1 (an average of $14.3 \%$ for spring forms and 15.8 for winter forms) (Table 1). Noteworthy is C18:2n6, whose average content for spring genotypes was $13.3 \%$ and $14.9 \%$ for winter genotypes (SM, Table 4, 7). Comparable values were obtained by Symoniuk and Hrastar et al. (16.5-18.\%) [3] and Vollamnn et al. (14.39-17.6) [28].

In the case of saturated acids, spring forms contained on average $5.2 \%$ of $\mathrm{C} 16: 0$ acid, while winter varieties $8.4 \%$ (SM, Table 3, 6). Similar results (5.55-6.97\%) were obtained for spring genotypes by Vollamann et al. in an experiment conducted in Austria [28]. The remaining acids were determined at about $0.1-2 \%$.

Investigating successive relationships between varieties and forms, one-way analysis of variance was performed using the non-parametric Kruskal-Wallis test for each acid separately (Table 2). No significant differences were found between C18:1, 18:2n6 and C20:1 acids in all genotypes. Based on the Kruskal test, differences were found in the mean concentrations of C18:3n3, C18:3n6, C20:2 and C22:1 acids in all genotypes, and then the Dunn test was performed to determine homogeneous groups. Genotype groups were obtained after performing the tests. Acid contents in genotypes belonging to the same group did not differ significantly, while the values belonging to different groups were significantly different. Two winter genotypes (Maczuga and 15/2/3) and the spring genotype UP2017/02 had the significantly highest content of C18:3n6. This acid was not found in 40 of the analyzed genotypes. Genotypes CSSCAM31, CSS-CAM30, BRSCHW 28347, CSS-CAM36 and Kirgzkij showed the highest content of C18:3n3 (Fig. 3). The lowest $\mathrm{C} 18: 3 \mathrm{n} 3$ content was found in winter genotypes: K9/1, 15/2/3, Przybrodzka (winter form) and C5 genotypes (SM, Table 4, 7).

In the case of erucic acid, all winter camelina genotypes had a statistically lower content. The variety Luna did not contain this acid. Genotypes 13207372, 515, No402NC7, CSSCAM8, CSCROO, GiessenNr3, 1Slovenia and 516 were characterized by the highest content of $\mathrm{C} 20: 2$, and varieties 15/2/2, 15/2/3, K10/1 and Lenka - the lowest (SM, Table 3, $6)$.

Statistical tests presented above, carried out based on the results of chemical analyses, did not show any highly significant differences between the varieties; therefore, it was decided to carry out statistical analyses to determine similarities between varieties. Application of hierarchical methods for all acids and genotypes allowed to obtain a dendrogram (Fig. 4) illustrating the hierarchical structure of the set of varieties as a result of decreasing similarity between them. All investigated winter genotypes were included in one similarity group (group a). Genotypes contained in this group were the least similar to the rest of the analyzed genotypes. Spring genotypes were divided into 4 cluster groups (b-e). All Polish genotypes (except for the variety Borowska) and Ukrainian genotypes were assigned to groups c-e.

Table 2 Anova: Kruskal-Wallis test: $p$-values

\begin{tabular}{llllllll}
\hline Acid & $\mathrm{C} 18: 1$ & $\mathrm{C} 18: 2 \mathrm{n} 6$ & $\mathrm{C} 18: 3 \mathrm{n} 6$ & $\mathrm{C} 18: 3 \mathrm{n} 3$ & $\mathrm{C} 20: 1$ & $\mathrm{C} 20: 2$ & $\mathrm{C} 22: 1$ \\
\hline$p$-value & 0.9599 & 0.7971 & 0.0115 & 0.0189 & 0.9996 & $7.02 \mathrm{e}-07$ & $7.01 \mathrm{e}-07$ \\
\hline
\end{tabular}

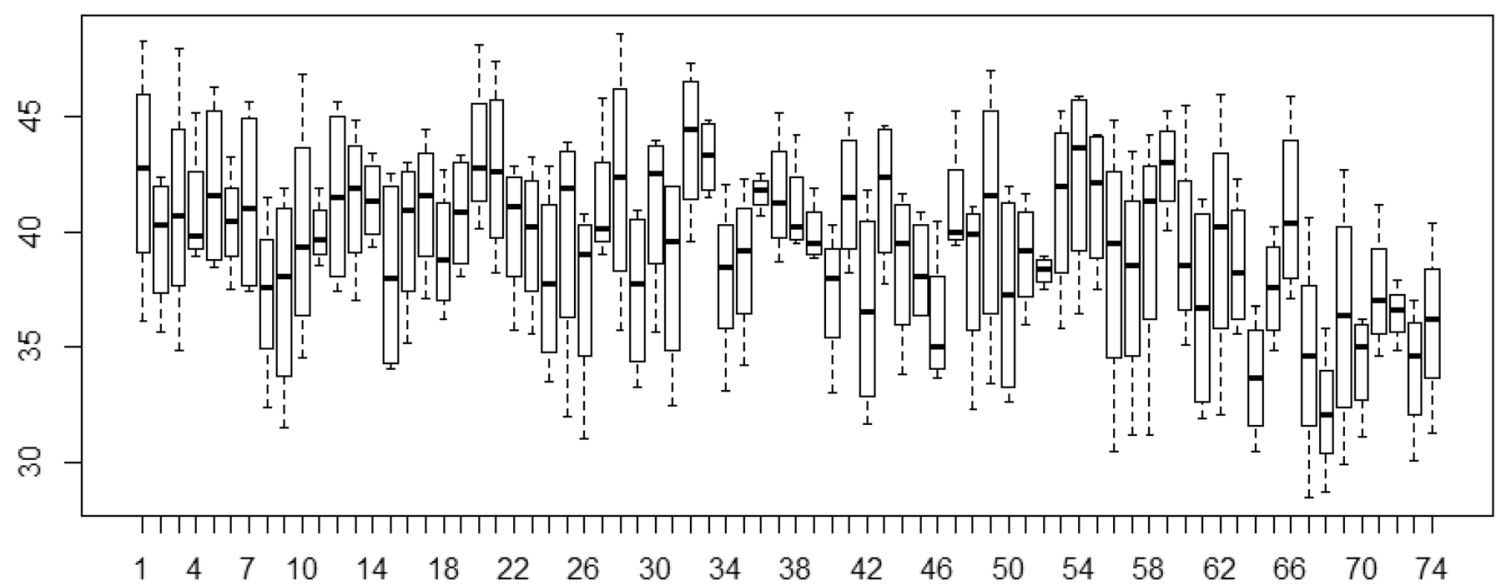

Fig. 3 Boxplots for the content of $\mathrm{C} 18: 3 \mathrm{n} 3$ in 63 spring and 11 winter genotypes of Camelina sativa 


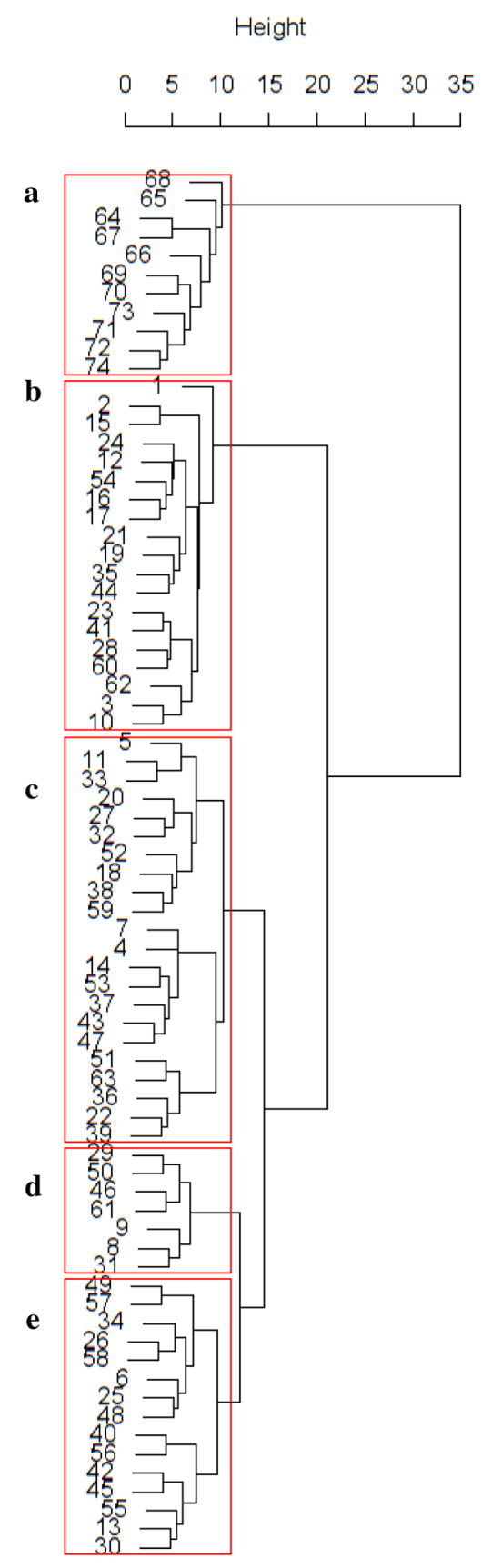

Fig. 4 The dendrogram of 63 spring and 11 winter genotypes of Camelina sativa

The variety Przybrodzka — an old Polish winter variety of camelina-deserves attention. Most of the winter camelina forms studied here were the result of long-term breeding after irradiation in 1993 of the variety Przybrodzka with four doses of gamma rays (0 Gy, $200 \mathrm{~Gy}, 400 \mathrm{~Gy}, 600 \mathrm{~Gy})$ from the ${ }^{60} \mathrm{Co}$ source [29]. In the studies of Kurasiak-Popowska et al. and Sobiech et al. [29, 30], the variety Przybrodzka was characterized by the lowest genetic similarity to other camelina genotypes, as determined by RAPD and SSR molecular markers. The variety Przybrodzka, assigned to winter genotypes, has been cultivated in Wielkopolska for many years. The variety Przybrodzka, donated by the Institute of Soil Science and Plant Cultivation (Poznań, Poland) to the US National Plant Germplasm System (NPGS) in 1966, was also used in the study. This genotype was included in the NGGS as a spring form. Therefore, when camelina genotypes were imported from NPGS from the USA in 2013, the variety Przybrodzka (from NPGS) was sown together with spring genotypes. The variety Przybrodzka (from NPGS) was included in the group of other spring genotypes, while the variety Przybrodzka (always cultivated as a winter form) was assigned to the group with other winter genotypes. And the distance between the two varieties was 7.7877.

The winter variety Grodziska and the spring genotype CSS-CAM34 as well as Gissen \#3 and the variety Borowska were characterized by the highest genetic similarity among the studied objects. The lowest genetic similarity was observed between C5 and CSS-CAM30. Winter mutation line $\mathrm{C} 5$ differed the most from the whole analyzed pool of genotypes.

\section{Summary}

Chemical analyses and result compilation using statistical methods allowed to verify the assumed research hypotheses. Hence, it was found that weather conditions deviating from the long-term average, both in terms of temperature and precipitation, did not affect the quantitative profile of fatty acids.

When analyzing a representative number of Camelina sativa spring and winter genotypes, no significant differences were found between the genotypes. However, differences between the functional forms of camelina were observed in the content of certain acids (C18:3n $3, \mathrm{C} 18: 3 \mathrm{n} 6$, C20:2, C22:1). Over the 4 years, no differences were observed between the spring and winter forms in in the fatty acid profile.

On the basis of observations made in this study, it was found that in contrast to other oil plants, spring and winter forms of Camelina sativa retained a constant fatty acid composition regardless of changing weather conditions. These results show the wide possibilities of camelina cultivation even in changing and unfavorable weather conditions, while preserving high quality of seeds, and hence high quality of camelina oil with a repeatable composition.

Acknowledgements We would like to kindly thank Paweł Poślednik for technical assistance.

Funding This research was funded by Poznan University of Life Sciences (Grant Number 508.102.00). 


\section{Compliance with ethical standards}

Conflict of interest The authors declare no conflict of interest.

Ethical approval This article does not contain any studies with human or animal subjects.

Open Access This article is licensed under a Creative Commons Attribution 4.0 International License, which permits use, sharing, adaptation, distribution and reproduction in any medium or format, as long as you give appropriate credit to the original author(s) and the source, provide a link to the Creative Commons licence, and indicate if changes were made. The images or other third party material in this article are included in the article's Creative Commons licence, unless indicated otherwise in a credit line to the material. If material is not included in the article's Creative Commons licence and your intended use is not permitted by statutory regulation or exceeds the permitted use, you will need to obtain permission directly from the copyright holder. To view a copy of this licence, visit http://creativecommons.org/licenses/by/4.0/.

\section{References}

1. Czernecki B, Taszarek M, Kolendowicz L, Konarski J (2016) Relationship between human observations of thunderstorms and the PERUN lightning detection network in Poland. Atmos Res 167:118-128. https://doi.org/10.1016/j.atmosres.2015.08.003

2. Woś A (2010) Klimat Polski w drugiej połowie XX wieku., Wydawnictwo. Poznań

3. Niedźwiedź T, Twardosz R, Walanus A (2009) Long-term variability of precipitation series in east central Europe in relation to circulation patterns. Theor Appl Climatol 98:337-350. https://doi. org/10.1007/s00704-009-0122-0

4. Daryanto S, Wang L, Jacinthe P-A (2017) Global synthesis of drought effects on cereal, legume, tuber and root crops production: a review. Agric Water Manag 179:18-33. https://doi. org/10.1016/j.agwat.2016.04.022

5. Hunsaker DJ, French AN, Clarke TR, El-Shikha DM (2011) Water use, crop coefficients, and irrigation management criteria for camelina production in arid regions. Irrig Sci 29:27-43. https ://doi.org/10.1007/s00271-010-0213-9

6. Berti M, Gesch R, Eynck C et al (2016) Camelina uses, genetics, genomics, production, and management. Ind Crops Prod 94:690710. https://doi.org/10.1016/j.indcrop.2016.09.034

7. Budin JT, Breene WM, Putnam DH (1995) Some compositional properties of camelina (Camelina sativa $\mathrm{L}$. Crantz) seeds and oils. J Am Oil Chem Soc 72:309-315. https://doi.org/10.1007/BF025 41088

8. Nguyen HT, Silva JE, Podicheti R et al (2013) Camelina seed transcriptome: a tool for meal and oil improvement and translational research. Plant Biotechnol J 11:759-769. https://doi.org/10.1111/ pbi. 12068

9. Kurasiak-Popowska D, Graczyk M, Stuper-Szablewska K (2020) Winter camelina seeds as a raw material for the production of erucic acid-free oil. Food Chem 330:127265. https://doi. org/10.1016/j.foodchem.2020.127265

10. Gómez-Monedero B, Bimbela F, Arauzo J et al (2015) Pyrolysis of red eucalyptus, camelina straw, and wheat straw in an ablative reactor. Energy Fuels 29:1766-1775. https://doi.org/10.1021/ ef5026054

11. Kurasiak-Popowska D, Stuper-Szablewska K, Nawracała J (2017) Camelina oil as a natural source of carotenoids for the cosmetic industry. Przem Chem 96:2077-2080
12. Kim N, Li Y, Sun XS (2015) Epoxidation of Camelina sativa oil and peel adhesion properties. Ind Crops Prod 64:1-8. https://doi. org/10.1016/j.indcrop.2014.10.025

13. Zubr J (1993) New source of protein for laying hens. Food Compd 13:23-25

14. Hixson SM, Parrish CC (2014) Substitution of fish oil with camelina oil and inclusion of camelina meal in diets fed to Atlantic cod (Gadus morhua) and their effects on growth, tissue lipid classes, and fatty acids. J Anim Sci 92:1055-1067. https://doi. org/10.2527/jas.2013-7146

15. Woyengo TA, Patterson R, Slominski BA et al (2016) Nutritive value of cold-pressed camelina cake with or without supplementation of multi-enzyme in broiler chickens. Poult Sci 95:2314-2321. https://doi.org/10.3382/ps/pew098

16. Zubr J (1997) Oil-seed crop: Camelina sativa. Ind Crops Prod 6:113-119. https://doi.org/10.1016/S0926-6690(96)00203-8

17. Schulte LR, Ballard T, Samarakoon $T$ et al (2013) Increased growing temperature reduces content of polyunsaturated fatty acids in four oilseed crops. Ind Crops Prod 51:212-219. https://doi. org/10.1016/j.indcrop.2013.08.075

18. Jiang Y, Caldwell CD, Falk KC (2014) Camelina seed quality in response to applied nitrogen, genotype and environment. Can J Plant Sci 94:971-980. https://doi.org/10.4141/cjps2013-396

19. Rodríguez-Rodríguez MF, Salas JJ, Venegas-Calerón M et al (2016) Molecular cloning and characterization of the genes encoding a microsomal oleate $\Delta 12$ desaturase (CsFAD2) and linoleate $\Delta 15$ desaturase (CsFAD3) from Camelina sativa. Ind Crops Prod 89:405-415. https://doi.org/10.1016/j.indcrop.2016.05.038

20. Izquierdo NG, Martínez-Force E, Garcés R et al (2016) Temperature effect on triacylglycerol species in seed oil from high stearic sunflower lines with different genetic backgrounds. J Sci Food Agric 96:4367-4376. https://doi.org/10.1002/jsfa.7646

21. Righini D, Zanetti F, Martínez-Force E et al (2019) Shifting sowing of camelina from spring to autumn enhances the oil quality for bio-based applications in response to temperature and seed carbon stock. Ind Crops Prod 137:66-73. https://doi.org/10.1016/J. INDCROP.2019.05.009

22. Jiang Y, Caldwell CD, Falk KC et al (2013) Camelina yield and quality response to combined nitrogen and sulfur. Agron $\mathrm{J}$ 105:1847. https://doi.org/10.2134/agronj2013.0240

23. Rodríguez-Rodríguez MF, Sánchez-García A, Salas JJ et al (2013) Characterization of the morphological changes and fatty acid profile of developing Camelina sativa seeds. Ind Crops Prod 50:673-679. https://doi.org/10.1016/J.INDCROP.2013.07.042

24. Symoniuk E, Ratusz K, Ostrowska-Ligęza E, Krygier K (2018) Impact of selected chemical characteristics of cold-pressed oils on their oxidative stability determined using the rancimat and pressure differential scanning calorimetry method. Food Anal Methods 11:1095-1104. https://doi.org/10.1007/s12161-017-1081-1

25. Ratusz K, Symoniuk E, Wroniak M, Rudzińska M (2018) Bioactive compounds, nutritional quality and oxidative stability of cold-pressed camelina (Camelina sativa L.) Oils. Appl Sci 8:2606. https://doi.org/10.3390/app8122606

26. Gugel RK, Falk KC (2006) Agronomic and seed quality evaluation of Camelina sativa in western Canada. Can J Plant Sci 86:10471058. https://doi.org/10.4141/P04-081

27. Vollmann J, Eynck C (2015) Camelina as a sustainable oilseed crop: contributions of plant breeding and genetic engineering. Biotechnol J 10:525-535. https://doi.org/10.1002/biot.201400200

28. Vollmann J, Moritz T, Kargl C et al (2007) Agronomic evaluation of camelina genotypes selected for seed quality characteristics. Ind Crops Prod 26:270-277. https://doi.org/10.1016/j.inder op.2007.03.017

29. Kurasiak-Popowska D, Tomkowiak A, Człopińska M et al (2018) Analysis of yield and genetic similarity of Polish and Ukrainian 
Camelina sativa genotypes. Ind Crops Prod 123:667-675. https:// doi.org/10.1016/j.indcrop.2018.07.001

30. Sobiech Ł, Grzanka M, Kurasiak-Popowska D, Radzikowska D (2020) Phytotoxic effect of herbicides on various camelina [Camelina sativa (L.) crantz] genotypes and plant chlorophyll fluorescence. Agric. https://doi.org/10.3390/agriculture10050185
Publisher's Note Springer Nature remains neutral with regard to jurisdictional claims in published maps and institutional affiliations. 